\title{
Contemporary Nepali Arts: Blurring the Boundaries among Art Genres
}

\author{
Yam Prasad Sharma*
}

\begin{abstract}
Some contemporary Nepali artworks have blurred the boundaries among different art genres like sculpture, painting, music, drama, photography and literature. In a single artwork, we can view the elements of two or more art forms. Three dimensional real objects are put on the two dimensional surface like canvas. Three dimensions are the special characteristics of sculpture whereas there are only two dimensions in painting. Three dimensions in the painting are illusions created by the use of light and shade, and gradation of colors. Artists use photographs and paintings simultaneously in the same work. They take references from photographs and present them in canvas. They also present their paintings, sculptures and photographs along with music, recitation of poems and performance. Some of their canvases present painting and poem side by side in the single space. Both visual art and verbal art coexist in the single canvas. The artists' creative urge goes beyond all boundaries, codes and established rules of arts. They do not follow the conventional techniques of creating arts. They experiment with forms, techniques, contents and medium. A single artwork has its own way of creation which may not be applicable to other artworks created by the same artist. The artist does not follow these trends but his work may set the new trend for other artists.
\end{abstract}

Key Words: Blurring the boundary, genre, inter-art, inter-textual, open-ended, plural

\section{Introduction}

Some contemporary Nepali arts break the boundaries among various art genres like painting, sculpture, architecture, literature, music, drama and photography. They do not follow the techniques, rules and conventions of particular genre of art. The artists do not follow the tradition but create their own codes and rules that are applicable only to their own works.

They use colors and inscribe words on their canvas. Two dimensional artworks like paintings and photography come together with three dimensional arts like sculpture and architecture. Even three dimensional real objects are found on their canvas. In some works, the artist himself performs as in drama accompanied with music. Some artworks share

* Dr. Sharma is lecturer in English at Lalitkala Campus, Tribhuvan University, Kathmandu, Nepal. 
the techniques of comic stripes. They present pictures with dialogue in texts in graphic bubbles. In other words, his artworks have inter-art relationship, that is, one art form is related to another art form. Their creations share techniques of multiple art genres. They blur the boundaries among art genres giving emphasis to his expression in response to contemporary socio-political condition.

Artworks go beyond the conventional limitations of different art genres like painting, sculpture, architecture, photography, drama, dance, music and literature. Before exploring the interrelationship of various art genres, I would like to discuss some essential elements of these various art forms so that it would be easier how the artists have gone beyond the conventional codes of art genres breaking their boundaries.

\section{Art Genres}

There are various art genres, and they have certain essential elements, codes and rules. For example, sculpture is three dimensional art form. Clay, stone, wood and metal are its media. It has volume, weight and tactile sensation, that is, it arouses our hands to touch it. On the other hand, architecture is aesthetic as well as functional art which is carved in space.

Painting uses canvas and colors. Colors are applied on canvas and images are created to convey the artist's expression. A painting can be landscape, portrait, still life or a composition. On the other hand, a painting can be realistic or abstract. Realistic painting represents the objects and events of external world whereas abstract painting is free of figures and recognizable images of the external world. Painting is two dimensional art though three dimensions are created through the use of light and shade, and perspective. The third dimension in painting is only the illusion.

Sculpture, painting and architecture unfold in space but dance, music and literature unfold in time. Sculpture, architecture, painting, photography and dance are visual arts whereas literature is verbal art. Words are exploited to create stories and poems. Similarly, painting and sculpture are high arts whereas photography and film are considered as low art. All these art genres have their own special elements, properties and rules which are followed by many artists. But some of the artists of our time have broken the conventional boundaries of these art forms.

\section{Going beyond the Genre}

Some artists use photograph as a reference to their painting. Sometimes, they paste the photograph on the canvas and paint images around and over the photograph itself. Interpenetrating the boundary, photograph enters the painting. In other words, the painting does not only use colors and canvas but also photograph as its material. Some artists not 
only paint pictures on the canvas but also write poem on it. The visual art and verbal art come together. Literature enters the painting. Some sculptures have been painted. The surface of the sculpture functions as the canvas. On the other hand, three dimensional images or the objects of reality are stuck on the surface the canvas. Two dimensional and three dimensional arts come together blurring their conventional boundaries. Gallery Nine (2004) writes about its inter-art activities in its prospectus:

Mixing high and low art forms, merging the traditional and modern with the postmodern and experimental, Gallery Nine has established itself as a uniquely engaged, cutting-edge art space. It aims to enable artists and art lovers to open up to new ideas and new media, cross-pollinating their fields with others and infusing the arts, as a whole, with great liveliness. (Prospectus)

In such artworks, the connection of one text to other texts creates inter-textual network whereas the exploitation of multimedia and the techniques of various art genres creates inter-art relationship. As the artists cross the conventional principles of creation, the artworks become experimental.

Poems, stories and sometimes other texts may create visual picture through the use of verbal medium. A written text can be the "verbal reproduction of pictorial rhetoric" (Melville et al. 1995, p.8). Close relationship between painting and writing can be seen in Montaigne's lines from his "Essay 28". In this essay, he uses word "paint" for "write": "I do not paint being. I paint its transition: not a transition from one age to another . . but from day to day, from minute to minute" (qtd. in Marian 1995, p.213).

Similarly, some other renowned writers try to relate their verbal texts with visual picture. For example, Cleanth Brook title for his critical work is The Well-wrought Urn. In the same way, James Joyce entitles his novel as A Portrait of Artist as a Young Man. A book is the portrait picture. Furthermore, concrete poems make graphic pictures using texts. Such texts are not only poems but also visual images. In this way some contemporary artworks transgress the boundaries between different art genres.

Paintings and some visual artworks create musical effect with their rhythmic lines, curves, colors and sweeping brush strokes. For example, Piet Mondrian, a renowned modern artist creates musical effect through his painting. Poet painter Rabindranath Tagore (1989) says about the importance of rhythm in every form of art giving emphasis to inter-art relationship:

My pictures are my versification in lines. Only training which I had in my young days was the training in rhythm, the rhythm in thought, the rhythm in sound, one 
thing which is common to all arts is the principle of rhythm which transforms inert materials into living creations (qtd. in Archer 1989, p.50).

The common element of all the art genres is the rhythm. Tagore accepts the fact that there is rhythm in his paintings as there is music in his poems. Similarly, Martin and Jacobus (1991) describe the rhythm of abstract painting as "frozen music" (p.81). So, we can say that paintings and some other visual arts share the elements of music and poetry.

Visual arts of course create rhythm and music. In addition to this, they also arouse our tactile sensation, the sense of touching. Showing the interrelationships among visual, auditory and tactile sensations perceived from the colors and images, Gombrich (1992) writes:

We speak of loud colours or of bright sounds, and everyone knows what we mean. Nor are the ear and the eye the only senses that are thus converging to a common center. There is touch in such terms as velvety voice and a cold light, taste with sweet harmonies of colours or sounds, and so on. (p.1085)

Some artists can use the colors to create the musical, tactile and olfactory sensations. De Man (1988) depicts the relationship among language, music and painting that we should "recognize the necessity of a non-perceptual, linguistic moment in painting and in music, and learn to read pictures rather than to imagine meaning" (p.362). The elements of one art form are shared by another art form.

Pop artists paste collage of papers and fabric, and stick three dimensional things of daily life like wood, electric bulbs, wire and other similar materials on the canvas. Due to this, the painting appears to be three dimensional, and this is the characteristic of sculpture. Artists sometimes make the collage of mixed media. Some contemporary art forms do not fit into a preconceived early concept of either a painting or sculpture. The art works cross the boundary among different art genres.

Performance art also crosses artistic boundaries by mixing painting, music, text and theatrical performance. All these different art forms reinforce the expression of the performing artist whose role is central in the artwork. All these art forms are simultaneously presented creating inter-art relationship. In such artworks, there is the coexistence of high and socalled mass culture.

Contemporary Nepali artists like Kiran Manandhar, Sujan Chitrakar, Ashmina Ranjit and Rabin Koirala have also created artworks that have inter-art relationship. They do not follow the rules of traditional art genres. They write words and use photographs and real objects on his canvas. Even the audience becomes the constituent element in their artworks. The viewers themselves become creator. 
The artworks are inter-generic because they are interconnected with earlier paintings, share techniques of other art genres like sculpture, literature, music, photography, theatre and film. These artworks are heterogeneous and open-ended, so, their meanings are notcertain but relative and multiple.

Inter-textuality, open-endedness, plurality and contingency are the characteristics and features of such art forms. These arts become inter-textual by recycling the myths and reintegrating the earlier art forms. We can find the creative appropriation of tradition along with the use of allusion and pastiche in the artworks. They refer to earlier art forms for allusion, and sometimes use parts of other artworks in the single artwork to create pastiche.

The artwork "blurs genres, transgresses them, or unfixes boundaries that conceal domination or authority" (Cohen 2000, p.293). Such works are "multigeneric" having inter-art relationship (Rowe 1992). They are not governed by the pre-established codes and cannot be interpreted and judged on the basis of them. Rather they attempt to formulate their own rules in the work. According to Lyotard (1986):

The works he produces are not in principle governed by pre-established rules, and they cannot be judged according to a determining judgment, by applying familiar categories to the text or to the work. Those rules and categories are what the work of art itself is looking for. (p.81)

The artists invent new techniques and idioms for their expression by discarding the old ones. Thus, their works are experimental.

The significance of the art form is uncertain. Such artwork "defers any final answer, implying that all answers are relative and provisional" (Wain 1999, p.4). It "suspends answers and defers completion, though it does not ignore the possibility" (p.2).

Their significance is not fixed and certain. The constructed meaning is not transcendental and universal but plural, provisional and ever shifting. On the process of constructing meaning, dialogue and interaction take place among various art forms and genres. Both alien and native art forms are revised and re-interpreted breaking the boundary among various art forms and genres.

Inter-art relationship is one of the important features of contemporary arts. Three dimensional features of some contemporary paintings break the boundary between painting and sculpture. The texts on the canvas bring verbal and visual art together. The merging of photography and painting breaks the boundary between high art and so called low art. The 
use of acting in performance art brings drama and art together. Such features are dominant in Sujan Chitrakar's artworks.

Sujan Chitrakar's artwork Marks of our Time 2015 breaks the boundary between dramatic performance and painting, art and reality, creative artist and viewer. The artist's head has been saved. He takes out his shirts and the artist sits on a wooden seat. There are paint brushes and paints near the artist. Viewers go into the exhibition hall, take a paint brushes, dip it into the white color and put their signature on the body of the artist. When all the viewers do this activity, the body of the artist has been covered with white paint having strange images, figures, signs and strange texture. The human body becomes the canvas for creating painting. The tradition of using cloth's canvas has been altered. We can use conventional canvas, but this is not only the medium for the creation of art, there are multiple alternatives of canvas as human body.

In this artwork, the viewers become the artists. The creative artist has made such environment that when people go to view arts, unknowingly, they themselves become artists and the creator. The binary opposition of artist/ viewer has been subverted. The artist puts together the painting and the performance in the sense that in addition to the colors and canvas, one can view the acting and performance of both the viewers and the artist. Blurring the boundary between painting and the drama, two art genres come in the single space. The artist has broken the conventional codes between these two art genres. The artist does not follow the established rules but invents his own way of creation.

Chitrakar's artwork, Which one do you Want me to Put on? presents the theme of mask. In this work, the artist has used various aspects of different art genres like sculpture, painting, architecture, installation art and furniture design. The background has painted structure like the wall of a house. There are eight colorful bottles standing on floor. And on the bottles, glass slabs have been put to make the surface of the table. There are eight masks on the table. The masks have been painted in different colors signifying different characters. Colorful sand has been spread on the floor.

We can see the technique of painting used on the wall, floor, bottle and mask, for these articles have been painted with colors. The masks themselves are the example of sculpture. The painted wooden block and the readymade things like bottles have been brought and installed in certain setting. This is the aspect of installation art. The table is the design of furniture. The painted wall, carpet -like floor, the setting of room create a sense of architecture. Since the artist has exploited these several art forms in his artwork, it can be said that his work has blurred the boundary between various art genres. The artwork is neither only painting and sculpture nor only architecture but all of them. The artist breaks conventional codes and boundaries among various art genres, and invents his own rules to create his artworks. 
The title of the art suggests that the artist is in dilemma about putting on the mask. He says, "Which one do you want me to put on?" The title assumes that there is somebody in the room, he is asking the person to choose the mask for him. On the other hand, it can also be said that the artist may have asked this question to the viewers or audience. Here also the artist wants to use mask to hide something and to reveal something else.

Sujan Chitrakar's artwork Red, she is Red has blurred the boundary between visual image and verbal text or painting and poem. The artwork has red background on the canvas. In the foreground, the artist has inscribed, "Blossoms she Blossoms.....". The work deals about women's problem in patriarchal society. The artist says that when the girl blossoms or becomes matured, she bleeds, the girl becomes untouchable at the time of menstruation. When she gets married, she can be physically tortured. Sometimes, she may be killed if she has not brought enough dowry. The artist himself has created a poem on his artwork having similar significance:

red

she is red. vermillion-sindoor. she is capitulated for the sake of kanyadaan and killed for no $=$ dowry. she is red. crimson-blood. she silently consents to be circumcised.

she is red. scarlet-love. she is killed for the honour of her family.

red.

every month of purification. red.

nine months of pain. red. she is red.

(The poem comes together with the visual artwork.)

The artist has been inspired by tragic situation of girls and women circumsion that occurs without their consent in some cultures. The work is also about the honor killings of women for the sake of family's ego and vanity. In some cases, she is considered as witch. Furthermore, the artwork is about every month's bloodshed and nine months' pain. Exploiting visual images and verbal text, the artwork presents the women's painful condition in the society. Ignoring the conventional codes, the artist has given emphasis on the exploration of contemporary issues.

Similar trends can be seen in the artworks of Kiran Manandhar. He creates visual images on the discarded sacks and pastes a paper having poem on the canvas. He also makes the collage of Buddhist prayer flags on the canvas. He pours colors into the running river at the time of performing the play, River Stage by Abhi Subedi. The river becomes both the stage and the canvas. Ashmina Ranjit pours paints on the street to communicate her ideas along with people's procession including the artist herself. The public street becomes the canvas. Drama and painting have been brought together in the artwork. Likewise, artworks of Bhuvan Thapa, Rajan Kaphle, Sudarsan Rana and Rabin Koirala also integrate the 
elements of various art genres in their works. These artworks are plural and open ended having multiple significances.

\section{Conclusion}

Some contemporary Nepali arts present the visual and verbal texts simultaneously. The poems and paintings have been juxtaposed in the same canvas. The three dimensional objects are put on the canvas giving painting an aspect of sculpture. On the other hand, the sculptures are painted with colors to stress the artist's expression. Some artworks include paintings, sculptures, photographs, architecture, drama, verbal texts and other objects of daily use in the work of art. Some artists present their artworks with music, artist's theatrical performance and the other works of various genres including painting. In this sense, painting not only exists as an individual art form but also functions as a part of the whole work. Crossing the boundary between artist and audience, some artworks demand the viewer's participation in the creative process. Since the viewer takes part in the creation, the viewer becomes the artist. Three dimensional art like sculpture and two dimensional art like painting have been brought together. High art like sculpture and painting and low art like photography coexist in the same work. The artworks are inter-textual, open-ended and plural having inter-art relationship. The artists do not follow the conventional codes and rules of art but invent their own techniques for creation. Their concern is not the tradition, genres and rules but the expression of their concepts, feelings and emotions. Such artworks have the potentiality of multiple interpretations.

\section{References}

Archer, W. (1989). India and modern art. London: George Allen and Unwin.

Cohen, R. (2000). Do postmodern genres exist? Postmodern literary theory: An anthology.

Ed. Oxford: Blackwell, 293-309.

De Man, P. (1988). The resistance to theory. Modern criticism and theory. Ed. David Lodge. London: Longman, 265-276.

Delanty, G. (2000). Modernity and postmodernity: Knowledge, power and the self. London: SAGE.

Gallery Nine (2004). Prospective of the gallery. Kathmandu.

Gombrich, E. (1992). From representation to expression. Critical theory since Plato. Ed. Hazard Adams. New York: Harcourt Brace Jovanovich College, 1083-89.

Lyotard, J. (1986). Answering the question: What is postmodernism? The postmodern condition. Trans. R. Durand. Manchester: Manchester UP, 71-82. 
Marian, L. (1995). Topic and figures of enunciation: It is myself that I paint. Vision and textuality. Eds. Stephen Melville and Bill Readings. London: Macmillan, 195214.

Martin, F. and Jacobus, L. (1991). The Humanities through the arts. New York: McGrawHill Inc.

Melville, S. and Readings, B. (1995). Vision and textuality. London: Macmillan.

Rowe, J. (1992). Postmodernist studies. Redrawing the boundaries. Eds. Stephen Greenblatt and Giles Gunn. New York: The Modern Language Association of America, 179280.

Wain, L. (1999). Introduction: Postmodernism? Not representing postmodernism. Literary theories: A reader \& guide. Ed. Julian Wolfreys. New York: NYUP, 1-12. 